\title{
ESTIMATION OF PAPAYA LEAF AREA USING THE CENTRAL VEIN LENGTH
}

\author{
Eliemar Campostrini ${ }^{*}$; Osvaldo Kiyoshi Yamanishi ${ }^{2}$ \\ ${ }^{1}$ Lab. de Melhoramento Genético Vegetal/Fisiologia Vegetal - UENF/CCTA, Av. Alberto Lamego, 2000 - Horto - \\ CEP: 28015-620 - Campos dos Goytacazes, RJ. \\ ${ }^{2}$ Faculdade de Agronomia e Medicina Veterinária, UnB - CEP: 70910-970 - Brasília, DF. \\ *Corresponding author <campost@zappa.uenf.br>
}

ABSTRACT: Four genotypes of papaya (Carica papaya L.) two from the 'Solo' group (Sunrise Solo and Improved Sunrise Solo line 72/12) and two from the 'Formosa' group (Tainung 02 and Known-You 01), grown in Macaé, RJ, Brazil (lat. $22^{\circ} 24^{\prime} \mathrm{S}$, long. $41^{\circ} 42^{\prime} \mathrm{W}$ ), were used in this study. Twenty-five mature leaves from each genotype were sampled four and five months after seedling transplant to the field to determine the length of the leaf central vein (LLCV) and the leaf area (LA). According to covariance analyses there were no significant differences in the slope and intercept of the mathematical models calculated for each genotype. Thus, a single mathematical model ( $\log L A=0.315+1.85$ Log $L L C V, R^{2}=0.898$ ) was adjusted to estimate the $L A$ using the length of LLCV for the four genotypes. An unique model can be applied to estimate the LA for the four papaya genotypes using LLCV in the range from 0.25 to $0.60 \mathrm{~m}$, and for papaya trees 150 to 180 days after transplanting.

Key words: Carica papaya, mathematical model, genotypes

\section{ESTIMATIVA DA ÁREA FOLIAR DO MAMOEIRO UTILIZANDO O COMPRIMENTO DA NERVURA CENTRAL}

\begin{abstract}
RESUMO: Quatro genótipos de mamoeiro (Carica papaya L.), sendo dois do grupo 'Solo' (Sunrise Solo e Improved Sunrise Solo 72/12) e dois do grupo 'Formosa' (Tainung 02 e Known-You 01) cultivados em Macaé, RJ, Brasil, (lat. $22^{\circ} 24^{\prime} \mathrm{S}$, long. $41^{\circ} 42^{\prime} \mathrm{W}$ ) foram utilizados neste estudo. Folhas maduras foram coletadas no quarto e quinto mês após o transplantio para determinar a relação entre o comprimento da nervura central foliar (NCF) e a área foliar (AF). A declividade e o intercepto das retas calculadas para os quatro genótipos não apresentaram diferença significativa na análise de covariância. Portanto, o modelo matemático ( $\left.\log A F=0,315+1,85 \log N C F, R^{2}=0,898\right)$ foi ajustado para estimar a AF em função do comprimento da NCF. Um modelo único pode ser aplicado para estimar a AF dos quatro genótipos de mamoeiro utilizando os comprimentos da NCF compreendidos no intervalo de 25 e $60 \mathrm{~cm}$, em plantas com 150 a 180 dias após o transplantio.
\end{abstract}

Palavras-chave: Carica papaya, modelo matemático, genótipo

\section{INTRODUCTION}

Descriptions of canopy structure are essential to achieve and understand plant processes because of the profound influence that structure has on plant-environment interactions. The vegetation architecture not only affects exchanges of mass and energy between the plant and its environment, but it also may reveal a strategy of the plant for dealing with long-lasting evolutionary processes, such as adaptation to physical, chemical or biotic factors, by reflecting the organism's vital activity or peculiarities in growth and development (Norman \& Campbell, 1989).

Canopy structure affects other environmental factors such as air temperature, leaf temperature, atmospheric moisture, soil evaporation below the canopy, soil heat storage and soil temperature, precipitation interception, leaf wetness duration and others.

Leaves constitute the most important aerial organ of the plant, playing a major role in the anabolic activities by means of the so called "green pigment" or "chlorophyll", which they possess in abundance. This pigment is the sole medium of the photosynthetic process, which in turn is the major synthetic pathway operative in the plants. Hence, the total leaf area, which in the majority of cases has a direct bearing on the amount of chlorophyll, is an important parameter for assessing the ability of the plant to synthesize its dry matter (Prasada Rao et al., 1978).

It has been proposed that measurements of leaf area increase and duration offer an attractive alternative method of assessing the photosynthetic potential of a tree canopy (Landsberg, 1986). Recent studies and modeling of the interaction between dynamic radiation regimes and developing canopies have focused on the total interception of radiant energy as a predictor valuable for dry matter production (Kozlowski et al., 1991).

At any given site, where environmental conditions are favorable for photosynthesis, the amount of photosynthetic surface produced and its efficiency in 
light capture account for most of the variation in productivity (Cannell et al., 1997; Linder et al., 1985).

The most obvious method to obtain canopy structure information is by direct measurement of plant organs. These measurements may include areas, shapes, angles or even positions. Automatic planimeters of the laboratory type, require leaves to be destructively sampled (Norman \& Campbell, 1989). The measure can be laborious when in the case of leaves of complex morphology (number and size of the veins and geometry of the borders) as it is the case of papaya leaves.

The search of a simple and easy way to determine the area of papaya leaves that have a complex morphology is essential for the study of the canopy behavior of papaya trees. Thus, the development of a nondestructive method to determine the area of papaya leaves is important to obtain information on whole leaf area without loss of plant material, by direct measurement.

The present work attempted to estimate the leaf area of four papaya genotypes using the length of the leaf central vein.

\section{MATERIAL AND METHODS}

\section{Plant material and cultivation conditions}

Four genotypes of papaya (Carica papaya L.), two from the 'Solo' group (Sunrise Solo and Improved Sunrise Solo line 72/12) and two from the 'Formosa' group (Tainung 02 and Known-You 01), were cultivated under field conditions, at the PESAGRO-RIO/Experimental Station of Macaé, RJ, Brazil (lat. $22^{\circ} 24^{\prime} \mathrm{S}$, long. $41^{\circ} 42^{\prime} \mathrm{W}$ ), on an Ultisol. The soil was fertilized, the $\mathrm{pH}$ adjusted according to Marin et al. (1993) and soil moisture was maintained by regular irrigation.

\section{Determination of the length of the leaf central vein and leaf area}

One hundred and fifty days after transplanting, twenty-five leaves grown in full sunlight were sampled from each genotype, having lengths of the leaf central vein (LLCV) in the range of 0.25 to $0.60 \mathrm{~m}$. After the sampling the leaves were maintained in a thermal recipient with ice and transported to the laboratory located $100 \mathrm{~km}$ from the Experimental Station. At the laboratory the LLCV and the leaf area (LA) of all leaves were determined using, respectively, a millimeter ruler and an automatic leaf area meter (Model LI-3100, LI-COR, Lincoln, NE, USA).

\section{Data analysis}

Data were analysed using the statistical program MINITAB (Minitab Inc., State College, PA, USA).

The LLCV and LA from the four genotypes were adjusted according to a first degree mathematical model:

$$
\mathrm{Y}=\beta_{0}+\beta_{1} \mathrm{X}+\varepsilon
$$

where:

$Y=$ logarithm of the leaf-surface area (LA) $X=$ logarithm of the length of the leaf central vein (LLCV) $\varepsilon=$ random error $\beta_{0}=$ intercept $\beta_{1}=$ slope

One hundred and eighty days after transplant, other 25 leaves of all genotypes were sampled and the LLCV and their respective LA measured for the validation of the proposed model. These were adjusted according to a first degree mathematical model similar to the one described previously.

\section{RESULTS AND DISCUSSION}

According to covariance analysis there were no significant differences in the slope $(F=0.96, d f=3, p=0.41)$ and intercept $(F=1.36, d f=3, p=0.26)$ of the curves calculated for each genotype. Thus, a unique mathematical model was developed.

The results show a significance level of 0.004 for $\hat{\beta}_{0}$ and $<0.0001$ for $\hat{\beta}_{1}($ TABLE 1). Similarly, a significance

TABLE 1 - Analysis of the regression coefficients of the proposed mathematical model (PMM) and validation of the mathematical model (VMM) to estimate the area of papaya leaves using the length of the leaf central vein.

\begin{tabular}{|c|c|c|c|c|c|c|}
\hline \multirow[t]{2}{*}{ Regression Coefficients } & \multirow{2}{*}{$\begin{array}{c}\text { Estimated } \\
\text { PMM }\end{array}$} & \multirow{2}{*}{$\begin{array}{c}\text { Values } \\
\text { VMM }\end{array}$} & \multicolumn{2}{|c|}{$\hat{\mathrm{t}}$} & \multicolumn{2}{|c|}{$\hat{\mathrm{p}}$} \\
\hline & & & PMM & VMM & PMM & VMM \\
\hline$\hat{\beta}_{0}$ & $0.31 \pm 0.10$ & $0.38 \pm 0.16$ & 2.98 & 2.29 & 0.004 & 0.034 \\
\hline$\hat{\beta}_{1}$ & $1.85 \pm 0.06$ & $1.84 \pm 0.10$ & 27.92 & 17.60 & $<0.0001$ & $<0.0001$ \\
\hline
\end{tabular}

TABLE 2 - Variance analysis of the proposed mathematical model (PMM) and validation of the mathematical model (VMM) to estimate the area of papaya leaves using the length of the leaf central vein.

\begin{tabular}{ccccccccc}
\hline Source of variation & \multicolumn{2}{c}{ Degrees of Freedom } & \multicolumn{2}{c}{ Mean Square } & \multicolumn{2}{c}{ F } & \multicolumn{2}{c}{ P } \\
\cline { 2 - 10 } & PMM & VMM & PMM & VMM & PMM & VMM & PMM & VMM \\
\hline Regression & 1 & 1 & 1.2420 & 0.3706 & 779.35 & 309.82 & $<0.0001$ & $<0.0001$ \\
Residual & 89 & 19 & 0.0016 & 0.0012 & & & &
\end{tabular}


level of $<0.0001$ was observed for the linear regression (TABLE 2).

Figure 1 shows the relationship between the logarithm of LLCV and standardized residues. This indicates that the data follow a normal distribution in a logarithmic scale.

Similarly to the mathematical model, the results show a high significance level for $\hat{\beta}_{0}(0.034)$ and $\hat{\beta}_{1}$ $(<0.0001)$ linear regression (TABLE 1 and 2$)$.

The values related to $\hat{\beta}_{0}$ and $\hat{\beta}_{1}$ did not show significant differences for $p \leq 0.05$ (TABLE 1). The slope and intercept of the mathematical model and validation of the proposed mathematical model did not differ, conferring a good repeatability for this model. Figure 2 shows that relationship between logarithm of the length of leaf central vein and logarithm of leaf area of four papaya genotypes. Figure 3 shows the relationship between leaf area estimated using the proposed mathematical model and the leaf area measured using leaf area meter. A high correlation $(r=0.94)$ was obtained between the two variables. Hence, the proposed mathematical model may be used to estimate the area of papaya leaves.

\section{CONCLUSIONS}

The adjusted mathematical model (Log AF = $0.315+1.85$ Log LLCV, $R^{2}=0.898$ ) may be used to estimate the leaf area of the four papaya genotypes' (Sunrise Solo, Improved Sunrise Solo line 72/12, Tainung 02 and Known-You 01) for LLCV values in the interval from 0.25 to $0.60 \mathrm{~m}$.

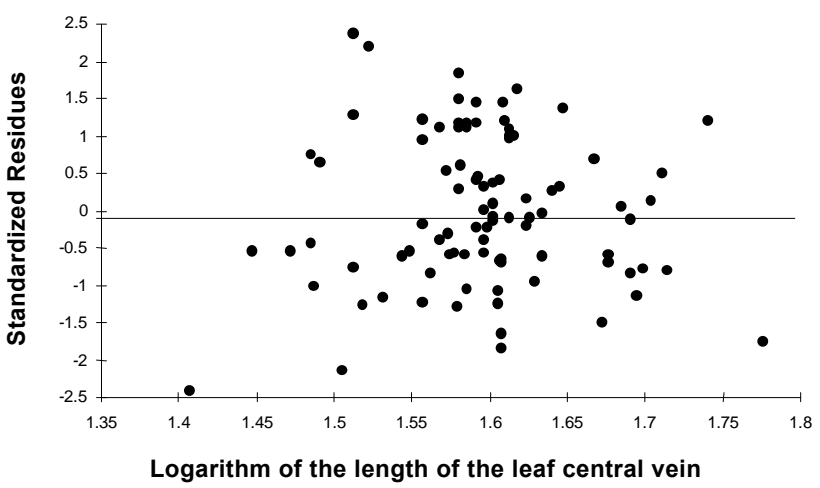

Figure 1 - Relationship between logarithm of the length of the leaf central vein and standardized residues to estimate papaya leaf area.

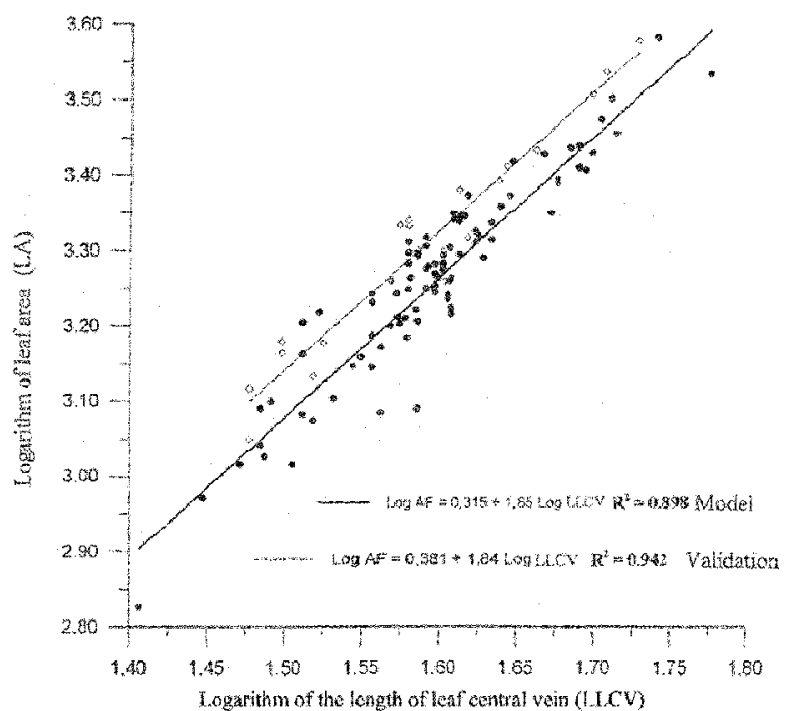

Figure 2 - Relationship between logarithm of the length of the leaf central vein and logarithm of leaf area of four papaya genotypes (Sunrise Solo TJ, Sunrise Solo 72/12, Tainung 02 e Know-You 01) to estimate the area of papaya leaves.

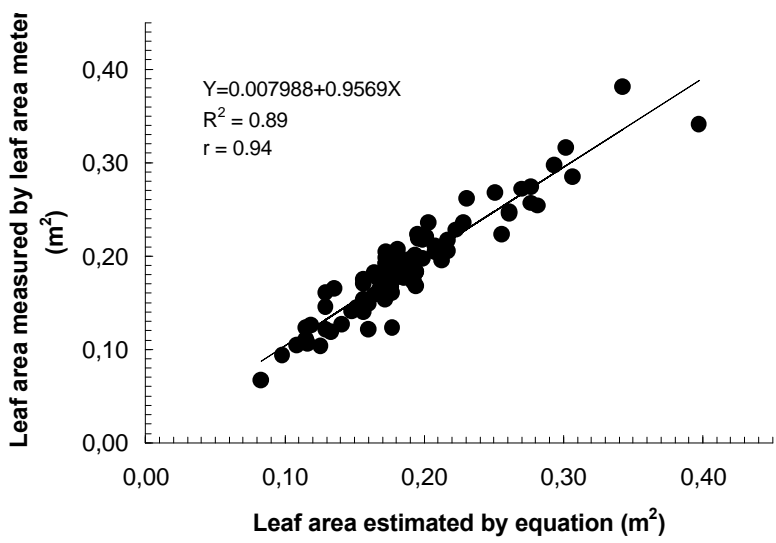

Figure 3 - Relationship between leaf area estimated using the equation of the proposed mathematical model with the area measured using a leaf area meter.

\section{ACKNOWLEDGEMENTS}

To Dr. Athayde Tonhasca Jr., Laboratório de Proteção de Plantas, Universidade Estadual do Norte Fluminense, for his assistance in the statistical analysis, and Dr. Richard lan Samuels and Dr. Athayde Tonhasca Jr. for their suggestions.

TABLE 3 - Covariance analysis of the proposed mathematical model with the validation data of the mathematical model used to estimate the area of papaya leaves using the length of the leaf central vein.

\begin{tabular}{cccccrc}
\hline $\begin{array}{c}\text { Source of } \\
\text { Variation }\end{array}$ & $\begin{array}{c}\text { Degrees of } \\
\text { Freedom }\end{array}$ & Sum of Squares & $\begin{array}{c}\text { Adjusted Sum of } \\
\text { Squares }\end{array}$ & $\begin{array}{c}\text { Adjusted Mean } \\
\text { Square }\end{array}$ & $F$ & $P$ \\
\hline LLCV & 1 & 1.5986 & 1.1450 & 1.1450 & 755.94 & 0.000 \\
$\hat{\beta}_{0}$ & 1 & 0.0491 & 0.0001 & 0.0001 & 0.09 & 0.770 \\
$\hat{\beta}_{1}$ & 1 & 0.0000 & 0.0000 & 0.0000 & 0.00 & 0.966 \\
Residual & 108 & 0.1636 & 0.1636 & 0.0015 & & \\
\hline
\end{tabular}




\section{REFERENCES}

CANNELL, M.G.R.; MILNE R.; SHEPPARD L.J.; UNSWORTH, M.H. Radiation interception and productivity of willow. Journal of Applied Ecology, v.24, p.261-278, 1997.

KOZLOWSKI, T.T.; KRAMER, P.J.; PALLARDY, S.G. The physiological ecology of woody plants. New York : Academic Press, 1991. 657p.

LINDER, S.; MCMURTRIE, R.E.; LANDSBERG, J.J. Growth of Eucalyptus: A mathematical model applied to Eucalyptus globulus. In: TIGERSTEDT, P.M.A; PUTTONEN, P.; KOSKI, V. (Ed.) Crop physiology of forest tree. Helsinki: Department of Plant Breeding, University of Helsinki, 1985. p.117-126.
MARIN, S.L.D.; GOMES, J.A.; SALGADO, J.S.; MARTINS, D.S.; FULLIN, E.A. Recomendações para a cultura do mamoeiro dos grupos 'Solo' e 'Formosa' no Estado do Espírito Santo. Vitória: Emcapa, 1993. (Circular Técnica, 3)

NORMAN, J.M.; CAMPBELL, G.S. Canopy structure,. In: PERCY R.W.; EHLERINGER, J.R.; MOONEY, H.A.; RUNDEL, P.W. (Ed.) Plant physiological ecology: field methods and instrumentation. New York: Chapman and Hall, 1989. p.301-325.

PRASADA RAO, G.S.; KHAN B.H.; CHADHA, K.L. Comparison of methods of estimating leaf-surface area through leaf characteristics in some cultivars of Mangifera indica. Scientia Horticulturae, v.8, p.341-348, 1978.

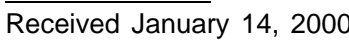

